\title{
E-Commerce Competence Assessment Mobile Application Development for SMEs in Thailand
}

https://doi.org/10.3991/ijim.v14i11.11358

\author{
Thipsuda Wongkhamdi, Nagul Cooharojananone ${ }^{(凶)}$, Jintavee Khlaisang \\ Chulalongkorn University, Bangkok, Thailand \\ Nagul.cechula.ac.th
}

\begin{abstract}
This research proposes a mobile application-based e-commerce competence assessment for SMEs in Thailand. The new e-commerce competence assessment is based on digital competence framework, e-commerce textbooks, training contents and experts' in-depth interview which their knowledge will help to identify the current e-commerce dimensions and indicators in Thailand. The proposed e-commerce competency framework comprises of 8 dimensions: 1) Information Processing and Technology 2) Communication and Collaboration 3) Content Creation 4) Safety, Security and Privacy 5) Problem Solving and Self Development 6) Business Fundamental 7) Legal and Regulations and 8) Language. These assessment dimensions are well suited for SME in Thailand. The dimensions are later developed in the form of mobile application using the waterfall model. The application is evaluated using Technology Acceptance Model (TAM). The mobile application is evaluated by 30 SME entrepreneurs. The results show that the use of the application (perceived usefulness) reveals the strengths, weaknesses and potential of SME entrepreneurs which are beneficial for the self-assessment of online selling skills $(\overline{\mathrm{x}}=4.50)$. For the perceived ease of use, result reveals that it is very easy to conduct a self-assessment through the application $(\overline{\mathrm{x}}=4.63)$. As for Attitude toward using the application was positive $(\overline{\mathrm{x}}=4.73)$. For the intention to use, SME entrepreneurs are willing to use this in the future $(\overline{\mathrm{x}}=4.57)$. It is also shown that $100 \%$ of 30 respondents are interested in using the system. This proposed application will help entrepreneurs to identify what improvements are needed and assist government authorities in viewing ecommerce competence reports in order to plan training sessions and strategies in order to improve entrepreneurs' e-commerce performances.
\end{abstract}

Keywords-E-Commerce, Technology Acceptance Model, Assessment, Competence, E-Commerce Competency

\section{Introduction}

At present, the internet is widespread. People around the world are able to communicate with each other without borders, including online trading, and there has been an increase in internet speed in order to support the increasing number of online trading in the world [1], [2]. E-Commerce is the fastest growing global retail channel and will continue to grow through 2022 [3]. According to eMarketer's estimates, e-commerce 
sales accounted for one-tenth of total retail sales worldwide in 2017. It is forecasted that sales will account for two-thirds of global e-commerce by 2021 for the Asia pacific region [4].

In Thailand, the Electronic Transactions Development Agency (ETDA), Ministry of Digital Economy and Society [5] conducted a survey comparing the behavior of internet users in 2019 with the survey results of Thai e-commerce from 2018. Data showed that $61.1 \%$ of respondents use the internet, an average increase of 3.50 hours from the previous year. As for the most popular activities on the internet, results showed that the majority of respondents use Social media (93.6\%), followed by email delivery (74.2\%), then information search (70.8\%), then TV and online music (60.7\%) and finally online purchases $(51.3 \%)$. This shows that online purchasing is one of the top five activities on the Internet. Furthermore, the number of uses increased by 50.8\% from 2017 with an additional surge of $51.3 \%$ in 2018 . This correlates to the survey results of the country's e-commerce, which has been continuously growing approximately $8-10 \%$ per year as revealed in the Thailand E-Commerce Week 2019 survey on February 2, 2019 [6].

With the trend of online trading increasing both in the world and in the country, the Thai government has been encouraging everyone to have the knowledge and capability to sell online. This involves established training programs for entrepreneurs, such as Business Transformation to Digital Economy Project, SMEs GO Online Project and Digital OTOP Project in order to develop the capability of people both online and regarding ICT, namely skills in being a Smart ICT User in an enhanced ICT workforce with expertise and an international mindset [7]. Furthermore, the training develops business capabilities in people, SMEs and community enterprises to be able to compete in the modern world [8].

The competency development of SMEs should be systematically standardized so it could be used as a tool to develop the country's manpower more effectively [9]. Hence, for this study an E-Commerce Competency Framework was developed in order to evaluate individuals' e-commerce performance, which has been created as an e-commerce competency assessment mobile system. People are using the internet on their mobile phones more often in their daily life, whether it be during travelling or in public places [5], including using the internet on their mobile phones for text messaging, mobile banking, online reading, downloading software, online gaming and online courses, which are done anywhere and anytime. [10] [11].

This empirical study aims to develop an E-Commerce Competence Framework, which will be developed in the form of mobile applications and used to investigate the adoption of e-commerce competency assessment systems. This system can measure entrepreneurial competencies and will help entrepreneurs to identify the e-commerce knowledge gaps which needs improving. Furthermore, it can support the government in allocating budget for various training programs that are suitable for entrepreneurs. 


\section{Conceptual Background and Theory}

\subsection{Digital competence framework}

When developing applications, in this case, the e-commerce competence assessment system, it is necessary to have content for the application that can be used to assess entrepreneurs, that is, indicators of e-commerce competency. Therefore, a search was carried out on existing studies related to an e-commerce competency indicator on SCOPUS, ScienceDirect and google scholar website with the e-commerce competence framework and ecommerce competence keywords. While there exists no study on ecommerce competency development, the researchers found studies in other areas of competency development, e.g. medical [12] nursing [13] pharmaceutical and [14] physiotherapy [15]. Nonetheless, there exists a similar area of research on e-commerce competency, known as Digital Competence Framework [16], which is the ability in using a computer and the Internet in the digital era. Since electronic commerce, or e-commerce, is the buying and selling of goods and services on the Internet [17], e-commerce is taken to mean doing business electronically [18]. Furthermore, according to the World Trade Organization (WTO) [19], "E-commerce includes the production, advertising, sales and distribution of products traded and paid on the Internet, but delivered tangibly. All products delivered as well as information are digitalized through the Internet". This indicates that digital competency is the measure of computer and internet performance only. Therefore, product/service trading indicators must be applied together. This study proposes an E-Commerce competence framework, which uses digital competence framework as a grounded theory and E-Commerce Textbook Contents [20] and National ECommerce Training Contents [21] to established a questionnaire, which will be analyzed and summarized by e-commerce experts and proposed as new knowledge in the field of E-Commerce Competence Framework.

The Digital Competence Framework [16] comprises of 5 categories: 1). Information processing, 2). Communication, 3). Content Creation, 4). Safety and 5). Problem solving, and 22 indicators [22], as shown in Table 1.

The E-Commerce Textbook Contents [20] was utilized as a base theory in this research study. There are previous studies that used textbook contents to develop competency framework [13] [23] [24] [25]. The E-Commerce Textbook Contents are divided into 3 parts: Introduction about digital business and e-commerce, Strategy and Application, and Implementation, as shown in Table 2. 
Table 1. Digital Competence Framework

\begin{tabular}{|c|c|}
\hline Competence areas & 21 Competences \\
\hline 1. Information processing & $\begin{array}{l}\text { 1. I can look for information online using a search engine. } \\
\text { 2. I know not all online information is reliable. } \\
\text { 3. I can save or store files or content (e.g. text, pictures, music, videos, } \\
\text { web pages) and retrieve them once saved or stored. }\end{array}$ \\
\hline 2. Communication & $\begin{array}{l}\text { 1. I can communicate with others using mobile phone, Voice over IP (e.g. } \\
\text { Skype) e-mail or chat - using basic features (e.g. voice messaging, } \\
\text { SMS, send and receive e-mails, text exchange). } \\
\text { 2. I can share files and content using simple tools. } \\
\text { 3. I know I can use digital technologies to interact with services (as gov- } \\
\text { ernments, banks, hospitals). } \\
\text { 4. I am aware of social networking sites and online collaboration tools. } \\
\text { 5. I am aware that when using digital tools, certain communication rules } \\
\text { apply (e.g. when commenting, sharing personal information). }\end{array}$ \\
\hline 3. Content creation & $\begin{array}{l}\text { 1. I can produce simple digital contents (e.g. text, tables, images, audio } \\
\text { files) in at least one format using digital tools. } \\
\text { 2. I can make basic editing to contents produced by others. } \\
\text { 3. I know that contents can be covered by copyright. } \\
\text { 4. I can apply and modify simple functions and settings of software and } \\
\text { applications that I use (e.g. change default settings). }\end{array}$ \\
\hline 4. Safety & $\begin{array}{l}\text { I. I can take basic steps to protect my devices (e.g. using anti-viruses and } \\
\text { passwords). I know that not all online information is reliable. } \\
\text { 2. I am aware that my credentials (username and password) can be stolen. } \\
\text { 3. I know I should not reveal private information online. } \\
\text { 4. I know that using digital technology too extensively can affect my } \\
\text { health. } \\
\text { 5. I take basic measures to save energy. }\end{array}$ \\
\hline 5. Problem solving & $\begin{array}{l}\text { 1. I can find support and assistance when a technical problem occurs or } \\
\text { when using a new device, program or application. } \\
\text { 2. I know how to solve some routine problems (e.g. close program, re-start } \\
\text { computer, re-install/update program, check internet connection). } \\
\text { 3. I know that digital tools can help me in solving problems. I am also } \\
\text { aware that they have their limitations. } \\
\text { 4. When confronted with a technological or non-technological problem, I } \\
\text { can use the digital tools I know to solve it. } \\
\text { 5. I am aware that I need to update my digital skills regularly. }\end{array}$ \\
\hline
\end{tabular}

Table 2. E-Commerce Textbook Contents

\begin{tabular}{|l|l|}
\hline \multicolumn{1}{|c|}{ Part } & \multicolumn{1}{c|}{ Contents } \\
\hline Part 1 Introduction & 1. Introduction to digital business and e-commerce \\
\hline & 2. Marketplace analysis for e-commerce \\
\hline \multirow{4}{*}{ Part 2 Strategy and applications } & 3. Managing digital business infrastructure \\
\cline { 2 - 2 } & 4. E-environment \\
\cline { 2 - 2 } & 6. Supply chain management \\
\cline { 2 - 2 } & 7. E-procurement \\
\cline { 2 - 2 } & 8. Digital marketing \\
\hline Part 3 Implementation & 9. Customer relationship management \\
\cline { 2 - 2 } & 10. Change management \\
\cline { 2 - 2 } & 11. Analysis and design \\
\cline { 2 - 2 } & 12. Digital business service implementation and optimization \\
\hline
\end{tabular}


The National E-Commerce Training Contents [21], were used to create an E-Commerce Competency Framework to suit the Thai context, such as using online tools or applications that are suitable for the Thai online market, including laws and regulations in the country. The National E-Commerce Training Contents are provided by ETDA [26], a Thai government agency that oversees e-commerce in Thailand. The course contents were defined during brainstorming sessions by Thai e-commerce experts in various fields, including successful entrepreneurs in e-commerce in Thailand and related government agencies, such as the electronic commerce registration department. The course has 2 levels: Basic, suitable for entrepreneurs who are just starting to sell online and do not have much knowledge in online sales and Intermediate, suitable for entrepreneurs who have already sold something online and are familiar with using tools or applications, as shown in Table 3.

Table 3. Thailand National E-Commerce Training Contents

\begin{tabular}{|c|c|}
\hline Basic & Intermediate \\
\hline 1. What is Digital Economy & 1. Introduction to Digital Economy \\
\hline 2. Signing up and using an email account & 2. Opening an online store with ready-made websites \\
\hline $\begin{array}{l}\text { 3. Signing up and using Facebook account, } \\
\text { editing personal information, posting and } \\
\text { interacting }\end{array}$ & $\begin{array}{l}\text { 3. Creating and developing product information: Taking pho- } \\
\text { tos to look professional, writing product and store infor- } \\
\text { mation, shop contact information to increase credibility }\end{array}$ \\
\hline $\begin{array}{l}\text { 4. Creating Facebook Page, Creating online } \\
\text { store on Facebook }\end{array}$ & 4. Principles in writing contents promoting products or shops \\
\hline $\begin{array}{l}\text { 5. Creating an attractive picture for online } \\
\text { selling }\end{array}$ & 5. E-Payment methods \\
\hline 6. Creating attractive contents & $\begin{array}{l}\text { 6. E-Commerce registration: Increase credibility for online } \\
\text { stores, E-Commerce Fraud Prevention }\end{array}$ \\
\hline $\begin{array}{l}\text { 7. Editing images using mobile app - } \\
\text { Snapseed }\end{array}$ & $\begin{array}{l}\text { 7. Online advertising: Facebook Ads, Google AdWords, SEO, } \\
\text { SEM, Google search console, Measuring ads performance }\end{array}$ \\
\hline \multirow[t]{2}{*}{$\begin{array}{l}\text { 8. Conclusion How to do E-Commerce } \\
\text { business }\end{array}$} & 8. Marketing strategy for SMEs \\
\hline & 9. Conclusion \\
\hline
\end{tabular}

\subsection{Software development life cycle}

The Waterfall model, proposed by Royce in 1970 [27], is a linear software development life cycle (SDLC) model, also known as classical software lifecycle model. This model consists of requirements, design, implementation, verification, and maintenance. The Waterfall model is used in many areas, such as interactive systems design [28], the creation of learning systems [29] and the development of mobile applications [30] [31]. The application proposed in this study was designed and developed using the waterfall method. The Software part of the project is divided into sequential phases, with some overlaps and throw backs acceptable between phases, as shown in Figure 1. 


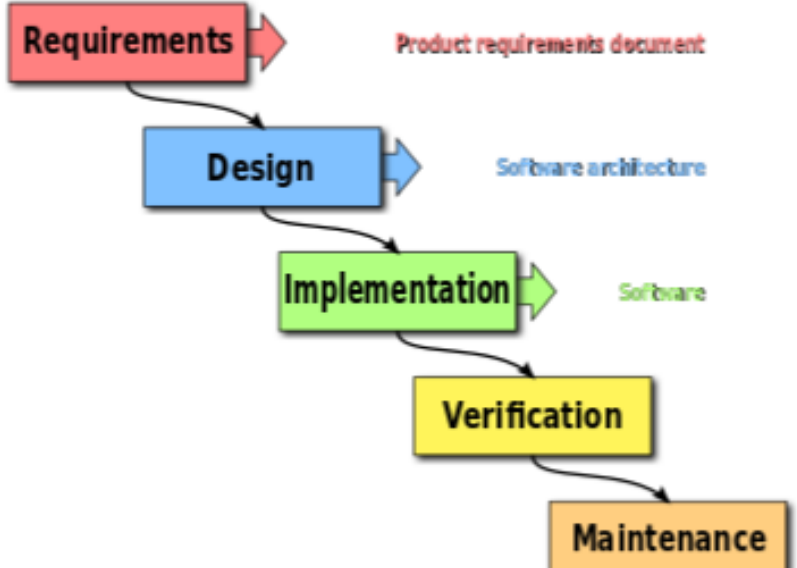

Fig. 1. Waterfall Model [32]

\subsection{TAM}

TAM, an Information Systems (IS) theory, was first proposed by Fred Davis in 1985 and is the most popular model used to explain and forecast the acceptance of a system. Davis proposed that system use can be explained by user motivation, which is directly influenced by the actual system's features and capabilities. After some modification, the final version of TAM was proposed by Davis in 1996 based on the theory of reasoned action [33] and other related research studies.

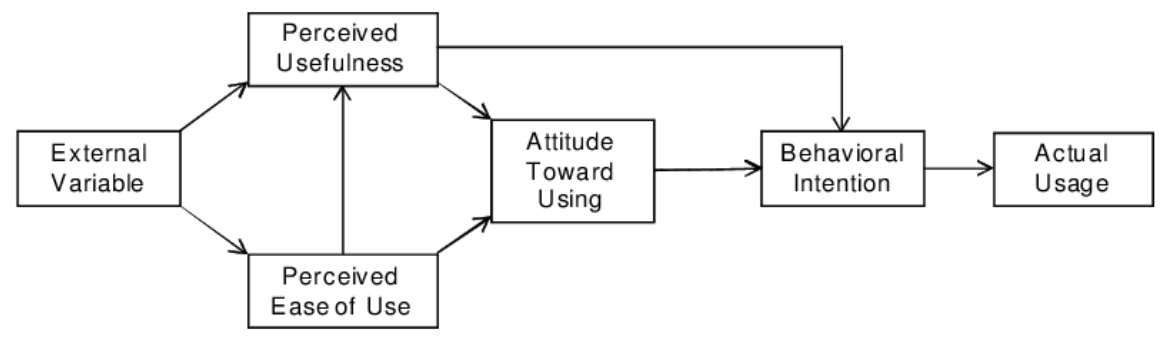

Fig. 2. Technology Acceptance Model (TAM)

Figure 2 outlines the Technology Acceptance Model (TAM), which is a theory that explains the perceived usefulness of information technology. The theory determines the perception of each individual on how information technology contributes to the development of operational efficiency and how it directly affects the intention of users' adoption behavior. Perceived ease of use is a factor that determines the level or success that has been met according to the needs or expectations and also affects the perception of the benefits derived from information technology [34]. Attitude toward using the tool is influenced by perceived usefulness and the ease of use of information technology. 
The behavioral intention is influenced by the attitude and the awareness of the benefits derived from information technology, which results in the actual use. Relevant studies around the world have confirmed that TAM was used as the core framework for analysis in order to understand the acceptance of the mobile system. One study investigates both the effects of the learning process in accepting smart mobile devices [35] and the teacher's attitude toward the use of mobile devices on the willingness to use smart mobile devices to teach natural sciences in kindergarten [36], [57], [58]. Another research examines how mobile applications could be adopted as tools for learning purposes in higher education institutions [37] and investigates motivations affecting the decision to adopt smartphones among university students [38]. Also for businesses that adopt the TAM model, an examination was conducted into mobile commerce adoption via mobile applications in the Malaysian market [39]. In summary, TAM is the most prevalent model and can be used as a tool to collect user's comments to improve the system.

Thus, for this research study, TAM was used as a core model to understand SMEs' attitude in using an E-Commerce Competence Assessment Mobile Application.

\section{Methodology}

In this section, the development of the framework and the application on how to explore system acceptance will be discussed. There are 3 steps involved, the first step must be developed in the content section and involves the e-commerce competence indicators that will be used to measure the ability of entrepreneurs. The second step will be the development of the application and once the application is completed, the user's acceptance toward the system acceptance will be examined as the final step.

\subsection{E-Commerce competence development}

Sampling and data collection: Interviews with experts were conducted whereby the sampling of respondents was divided into 3 groups: 1) Government officials responsible for e-commerce in the country 2) Entrepreneurs who have succeeded in online sales and 3) e-commerce training instructors at the national level. Three people were selected per group, totaling 9 people. Purposive sampling and snowball sampling methods were implemented. The criteria for selecting experts is that the individual must have worked in e-commerce for at least 3 years or have at least 3 years of experience in e-commerce sales or have been a coach/trainer for government agencies on e-commerce for at least 3 years. The sample size used in the research $\mathrm{N}=9$.

For the data collection, an email was sent to the related expert groups, which consists of the following: 3 people in the government sector, responsible for overseeing the country's e-commerce, consisting of 3 agencies, including The Office of SMEs Promotion (OSMEP) [40] Department of Business Development, Ministry of Commerce [41] and ETDA [5], 3 people from the e-commerce instructor group at the national level who are responsible for training SMEs in the country and 3 people from the group of entrepreneurs who have achieved success in online sales. An email containing details about 
the purpose and benefits of this research was sent to all relevant parties. The interviewees were asked to respond by email to indicate whether they are willing to participate in the research project. The researcher then emailed each individual in order to schedule a convenient date and time for the interview. Subsequently, the researcher conducted an in-depth interview with 6 open-ended questions to obtain expert opinions regarding the required e-commerce capabilities for each area. A sound recorder was used during the interviews in order to collect complete and detailed data. After the 9 participants were interviewed, the data was analyzed by using Content Analysis and the results were summarized as indicators for each aspect.

Questionnaire: This research uses open-ended questions as a tool for data collection. It consists of 6 dimensions, which are: 1) Information processing 2) Communication 3 ) Content Creation 4) Safety 5) Problem solving and 6) Suggestions. All the questions are based on the theory of Digital Competence Framework [16], E-Commerce Textbook Contents [20], and National E-Commerce Training Contents [21]. An indepth interview was carried out on 9 experts from 3 main government agencies [40], [41], [5] related to National e-commerce. Feedback was requested on the e-commerce performance indicators in each area, including indicators and additional suggestions.

Data analysis: When the interviews were completed, the data was transcribed and analyzed by Content Analysis to summarize the opinions of each expert. Additionally, each indicator was identified for each item and then taken into consideration to be grouped and summarized in order to develop the E-Commerce Competence Framework. The conclusion of the E-Commerce Competence Framework was then used to develop the application in the next step. The research methodology for this study is shown in Figure 3.

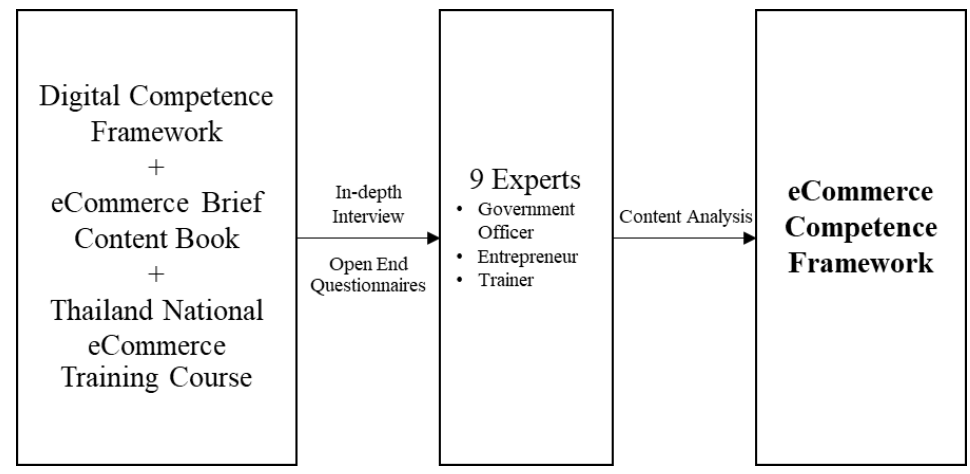

Fig. 3. Research Methodology

\subsection{Application development}

The development of the e-commerce competency assessment system involves a Software Development Life Cycle known as the Water Fall Model. It consists of requirements, design, implementation, verification, and maintenance. 
Requirements: For this step, data was collected. The government agencies [40], [41], [5], need to use the system to measure the e-commerce competency levels of entrepreneurs, which means the government agencies would need to see data report for 2 parts: 1) personal information, such as name, address, product type and sales experience and 2) e-commerce competency information in each area: used in strategic planning, training plans to educate entrepreneurs to gain knowledge, skills, and ability to sell online effectively.

Design: For the process of system design, system users were divided into 2 groups, which are Group 1: entrepreneurs and Group 2: government officers who must log in by inputting username and password. After login, entrepreneurs can go to self-test and obtain the report results, while government officers can view the entrepreneur competences' report. Subsequently, it can be written in the Use Case Diagram form, system overview and system architecture, all data will be stored and processed on Cloud.

Figure 4 shows the operating system diagram with the actions for entrepreneurs and government agencies, data imported by researchers or system developers.

Figure 5 shows the operating system diagram with the actions of government agencies, data imported by researchers or system developers.

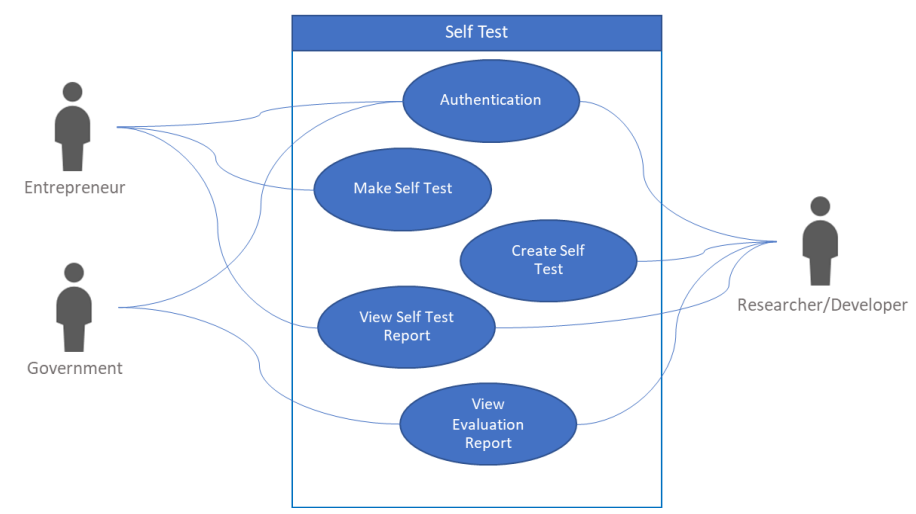

Fig. 4. Use Case Diagram\#1

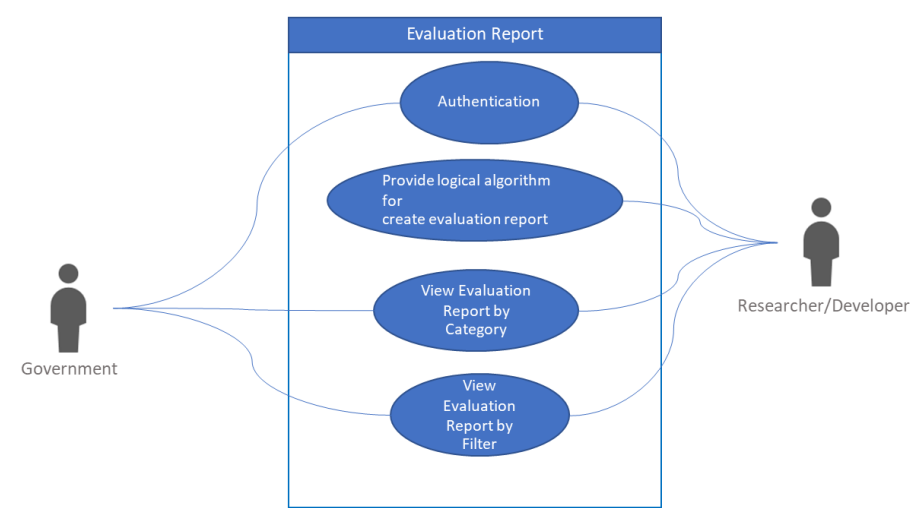

Fig. 5. Use Case Diagram \#2 


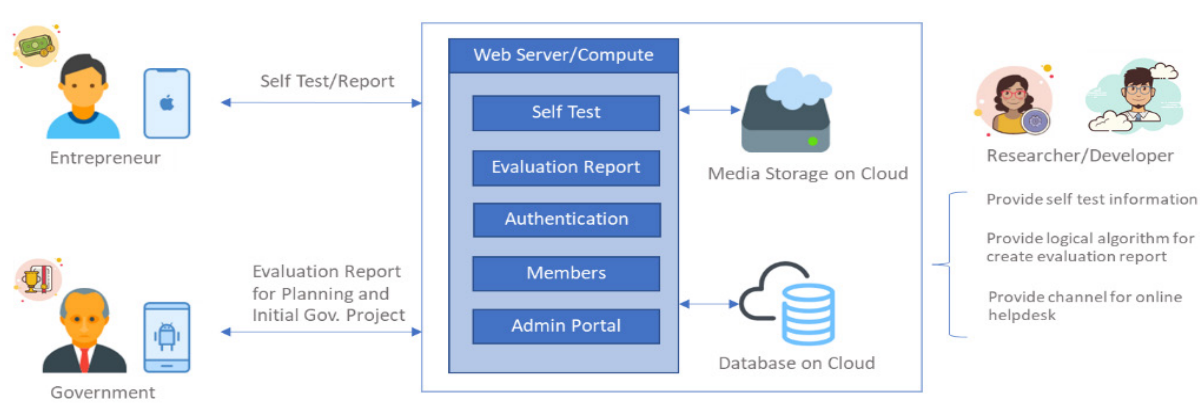

Fig. 6. System Overview

Figure 6 shows the overall system whereby entrepreneurs have to register as a member in order to complete the self-test. Subsequently, they can view the results of the self-test by calling the report and comparing the results within the group.

For the government officers, they can login from the account that the Admin has created to see the results of the self-test and browse reports in various formats. This will help gather information for creating a development plan for entrepreneurs in each project.

Researcher/Developer will prepare various information for the self-test, such as data, indicators, weight values, criteria and help desk through the Admin Portal and design the principle of evaluation reports for entrepreneurs and government officers.

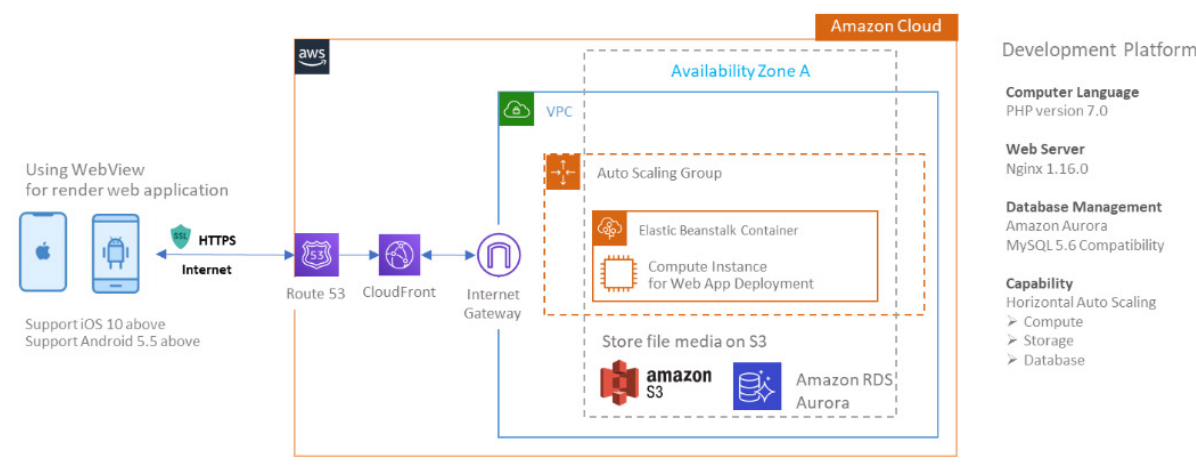

Fig. 7. System Architecture

Figure 7 shows the system architecture, whereby the completed developed system will be used via the Mobile Web Browser, i.e. iOS version 10 and above and Android 5.5 , depending on the minimum supported standard of each system. The completed system will be installed on Amazon's Elastic Beanstalk system to reduce costs as it can automatically be expanded. To accommodate a large number of users, this system will be developed in PHP version 7.0 with the Amazon Aurora database, which will be expanded from MySQL 5.6 and stored on Amazon S3 with security controls on Amazon standards. CloudFront will prevent DDOS and various cyber-attacks. 
Implementation: This part includes 2 main steps which are Development and Installation. For the Development step, the technology used to create systems includes Microsoft .NET CORE technology with HTML / CSS / HTML / CSS for all applications are stored on Aurora RDS (MySQL 5.6 Compatibility). The application deployed on Amazon public cloud will automatically be scaled when there is a high volume of traffic. Cloud Hosting is created to collect electronic commerce performance assessments and process and display the score report in various areas. The program will display the assessment form which enables the self-assessor to evaluate the e-commerce competency in various fields. In addition, the program will check the assessment form before submitting it to the system. It will then evaluate and report the individual results, which can be exported as files. The government agencies can view the entrepreneur performance report in various perspectives. For the Installation, since the system is set on Cloud, users will be able to access via Web Browser on mobile or PC/Mac.

Verification: For this step, the data filling and data storage, including the processed results, must be accurate and meet user expectation.

Maintenance: Finally, for this step, since the system is on the Cloud, it will be using the infrastructure of the Cloud service provider, which has a system that can support a large number of users.

\subsection{TAM}

When the application was developed, we explored the adoption of the application by using the questionnaires administered to users. This can help researchers improve the efficiency of the system.

In the process of technology adoption evaluation, we developed a tool by applying the "Technology Acceptance Model (TAM)" [34], which is a theory that describes the factors related to technology adoption and predicts user behavior in accepting newly developed information systems [42].

Sampling and data collection: The sample group used in this research is 30 people from SMEs who registered with OSMEP [40]. The sample size used in the research N $=30$ [43].

Questionnaire: This research uses a questionnaire as the tool for data collection, which consists of 2 parts: demographic and opinions on system adoption. Topics and questions of the questionnaire, which uses a 5-point Likert Scale, have been reviewed by experts to ensure validity and reliability.

Questionnaire reliability: The survey was categorized into 4 dimensions with 16 variables. Then questionnaire was sent to 30 entrepreneurs. The questionnaire was validated for reliability using Cronbach's alpha coefficient, which found that the values for all were higher than 0.7 indicating that the questionnaire is reliable.

Data analysis: The data were analyzed by Statistical Package for Social Sciences Program (SPSS), Version 20, which is a descriptive statistics tools for deriving percentages, means and standard deviation values: SD. 
Table 4. Questionnaire

\begin{tabular}{|c|c|c|}
\hline No & Questions & Reference \\
\hline & Perceived Usefulness & \\
\hline 1 & Using the application systematically reveals my strengths, weaknesses and potential. & [44] \\
\hline 2 & The application is beneficial for online sales self-assessment. & [45] \\
\hline 3 & The use of the application improves online sales performance. & [46] \\
\hline 4 & This application is an effective tool for online sales self-assessment. & [45] \\
\hline \multirow[t]{2}{*}{5} & In general, the application benefits your work. & [47] \\
\hline & Perceived Ease of Use & \\
\hline 6 & It is very easy to do the self-assessment in this application. & [44] \\
\hline 7 & I think this application is easy to use. & [48] \\
\hline 8 & It does not take a long time to learn to use the application. & [44] \\
\hline 9 & Using the application does not require studying the manuals. & [46] \\
\hline \multirow[t]{2}{*}{10} & In general, the application is easy to use. & [44] \\
\hline & Attitude Toward Using & \\
\hline 11 & Using this application is a good idea. & [45] \\
\hline 12 & I think that using the application is pleasant. & [49] \\
\hline \multirow[t]{2}{*}{13} & In general, the attitude toward this application is positive. & [45] \\
\hline & Behavioral Intention to Use & \\
\hline 14 & $\begin{array}{l}\text { I intend to recommend the use of this application to my friends who operate online busi- } \\
\text { nesses. }\end{array}$ & [46] \\
\hline 15 & I intend to use this application in the future. & [46] \\
\hline 16 & $\begin{array}{l}\text { I will definitively keep using this application for e-commerce competency self-assess- } \\
\text { ment. }\end{array}$ & [48] \\
\hline
\end{tabular}

Table 5. Cronbach's Alpha Coefficient for reliability analysis

\begin{tabular}{|l|c|c|}
\hline \multicolumn{1}{|c|}{ Dimension } & Number of indicators & Internal Consistency \\
\hline Perceived Usefulness & 5 & .766 \\
\hline Perceived Ease of Use & 5 & .848 \\
\hline Attitude Toward Using & 3 & .786 \\
\hline Behavioral Intention to Use & 3 & .835 \\
\hline
\end{tabular}

\section{$4 \quad$ Results}

\subsection{E-Commerce competence framework}

Based on the results of the interview, all 9 experts expressed similar opinions, which is that e-commerce competence should be based on Digital Competence, since e-commerce business is sales that occur online via the use mobile phones and computers, as well as an internet connection.

Therefore, in Dimension 1, Information Processing, entrepreneurs should have knowledge of product information searching and storing various images including product information onto the computer or mobile phones or stored on the Cloud so that product data can be used whenever they want. 
Dimension 2, Communication between seller and buyer, all parties must know how to use communication tools, such as email and instant messaging. Sellers should also be able to identify which channels each group of customers prefer, such as teens preferring Line or older people preferring to talk on the phone. Effective communication with the team means that everyone must know how to use communication and collaboration tools, such as Slack, Google drive or Dropbox.

Dimension 3 is Content Creation, which is very important. This includes product images, product details or product video, which must be presented interestingly in order to attract customers to buy products. Operators should know about using tools to create contents, such as photo / video editing programs.

As for Dimension 4, Safety, entrepreneurs must be careful about identity theft, password setting, privacy and maintaining customer information.

Dimension 5, Problem Solving, is also important because when conducting business there are various problems that entrepreneurs have to fix. Thus, there should be a plan to solve problems, such as late product delivery to customers, in which case sellers must have delivery details of carriers for customers to track. If there is a problem at work, they must find a solution by themselves. This can be done by searching the internet or developing their own strategy, such as taking courses in business or important up-todate technology.

The following 3 additional dimensions are extracted from experts' in-depth interview using content analysis. These 3 dimensions are not originally included in the standard digital competence framework. During the in-depth interview, experts agreed that the important competencies, which all businesses should have are, Dimension 6, the 4Ps, various business strategies, product manufacturing management, finance, logistic, customer service, etc. In addition, what SME entrepreneurs need to have are, Dimension 7, legal competency, rules, law and regulations which includes business law, tax and copyright. At the end, the experts agreed that, Dimension 8, language competency is necessary. Meaning that SME entrepreneurs should have knowledge of English and/or Chinese in order to find product information or create content via internet search engines or from foreign websites. Furthermore, e-commerce is a matter of trading without borders, therefore, it is necessary to communicate in English to both customers and suppliers. Subsequently, the data from the interview was synthesized using Content Analysis to summarize the various indicators, including a summary of various capabilities in each area. These 3 dimensions are suitable for the context of e-commerce for SME in Thailand, which are considered as new findings.

This can be summarized into E-Commerce Competence Framework by using the research framework to develop the system with 8 Dimensions, which are: 1) Information Processing and Technology 2) Communication and Collaboration 3) Content Creation 4) Safety, Security and Privacy 5) Problem Solving and Self Development 6) Business Fundamental 7) Legal and Regulations and 8) Language, and 62 indicators, as shown in Figure 8. 

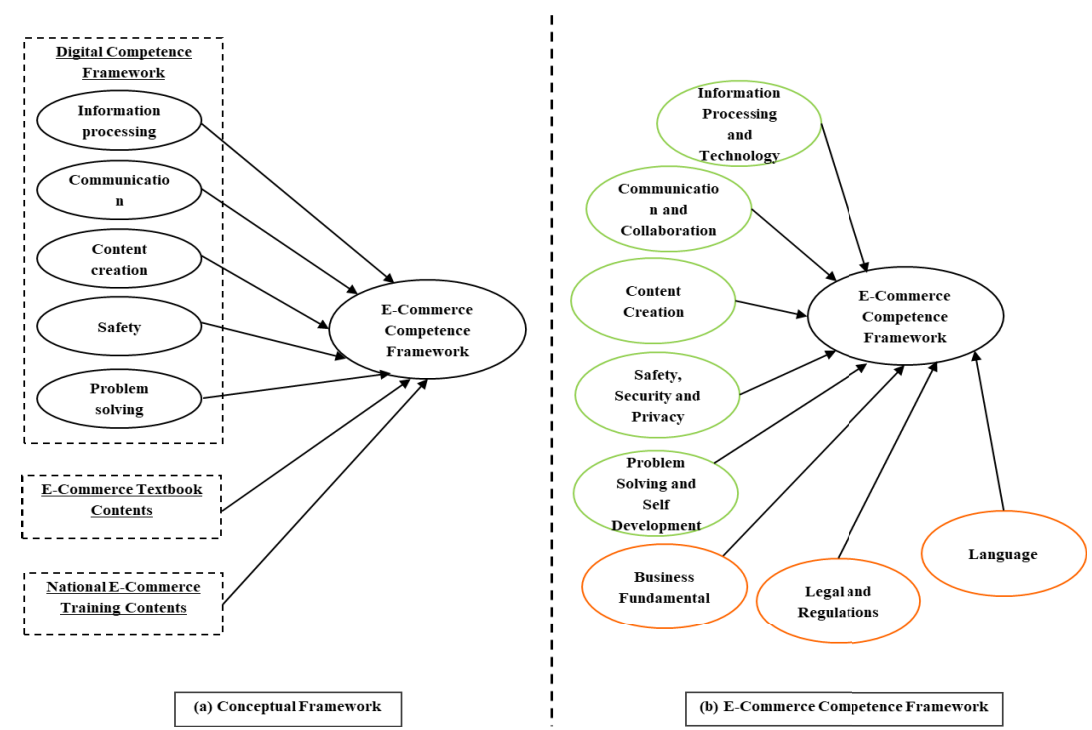

Fig. 8. (left) Combination between Standard Digital Competence Framework + Textbook Contents + Training Contents. (right) E-Commerce Competence Framework for SMEs in Thailand.

\subsection{Application}

Software development consists of the main screen, divided into 2 parts, which consists of the assessment section and report section.

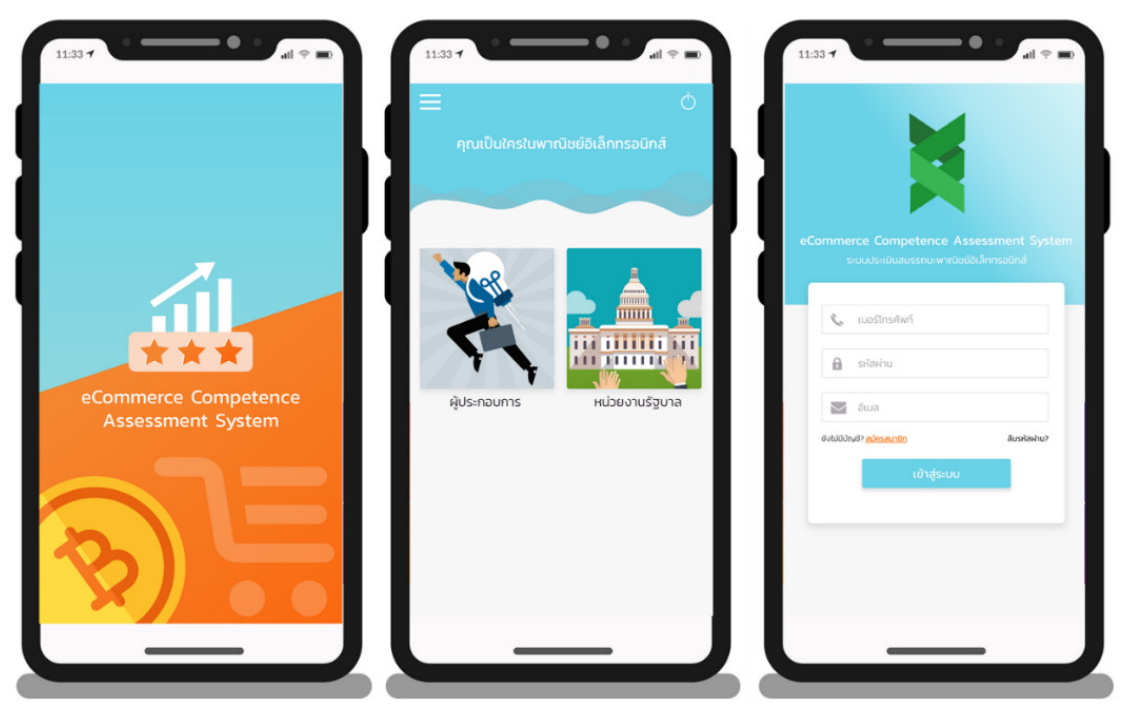

Fig. 9. Log-in screenshots for SMEs Entrepreneur 
Figure 9 shows the application screen for logging in, separating users into 2 groups, namely SMEs and government agencies. SMEs must login to enter the self-assessment section, which consists of 8 dimensions and 62 indicators.

The self-assessment question is a 5-level assessment and when the assessor completes the assessment the user will be able to promptly see the evaluation results. The system will display the results of all 8 dimensions, which indicate the level of knowledge in each area and the assessor can print out the assessment report and compare it with the average performance from the most recent 1,000 SMEs, as shown in Figure 10 .

Figure 11 shows the login screen for government authorities. They can access reports, which have 2 parts. Part 1 is the general report of all SMEs, including gender, age, area, product type and online business experience. Part 2 is the performance report, which can be selected and filtered by gender, age, area, product type and online business experience, as well as printed out in PDF format, as shown in Figure 12.

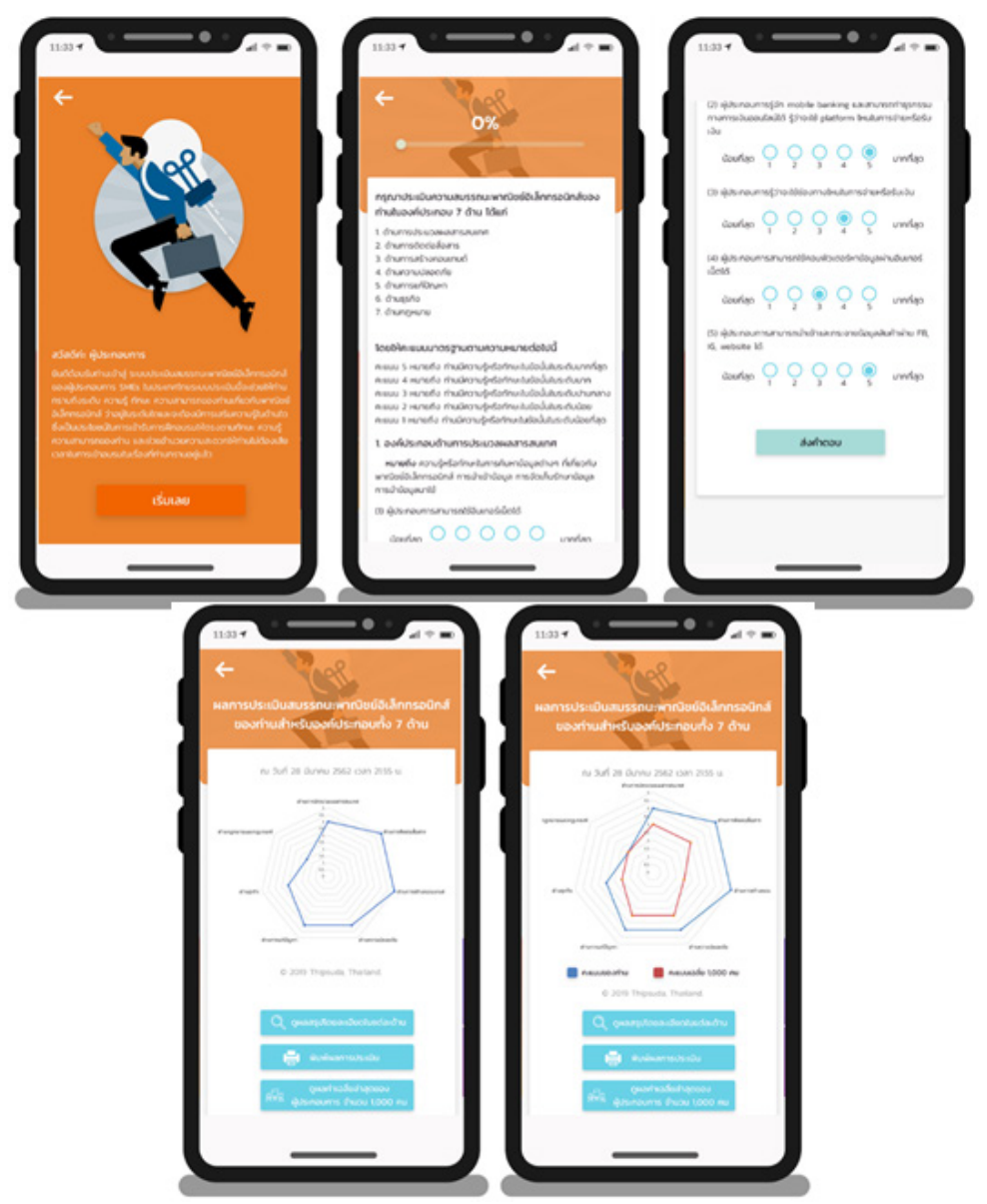

Fig. 10. SMEs self-assessment screenshots 


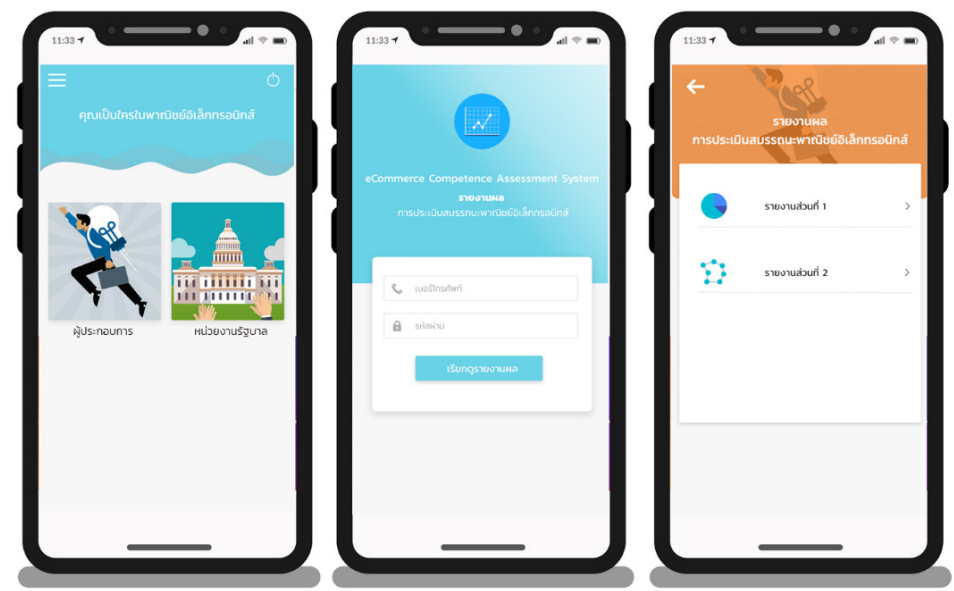

Fig. 11. Log-in screenshots for Government Agency

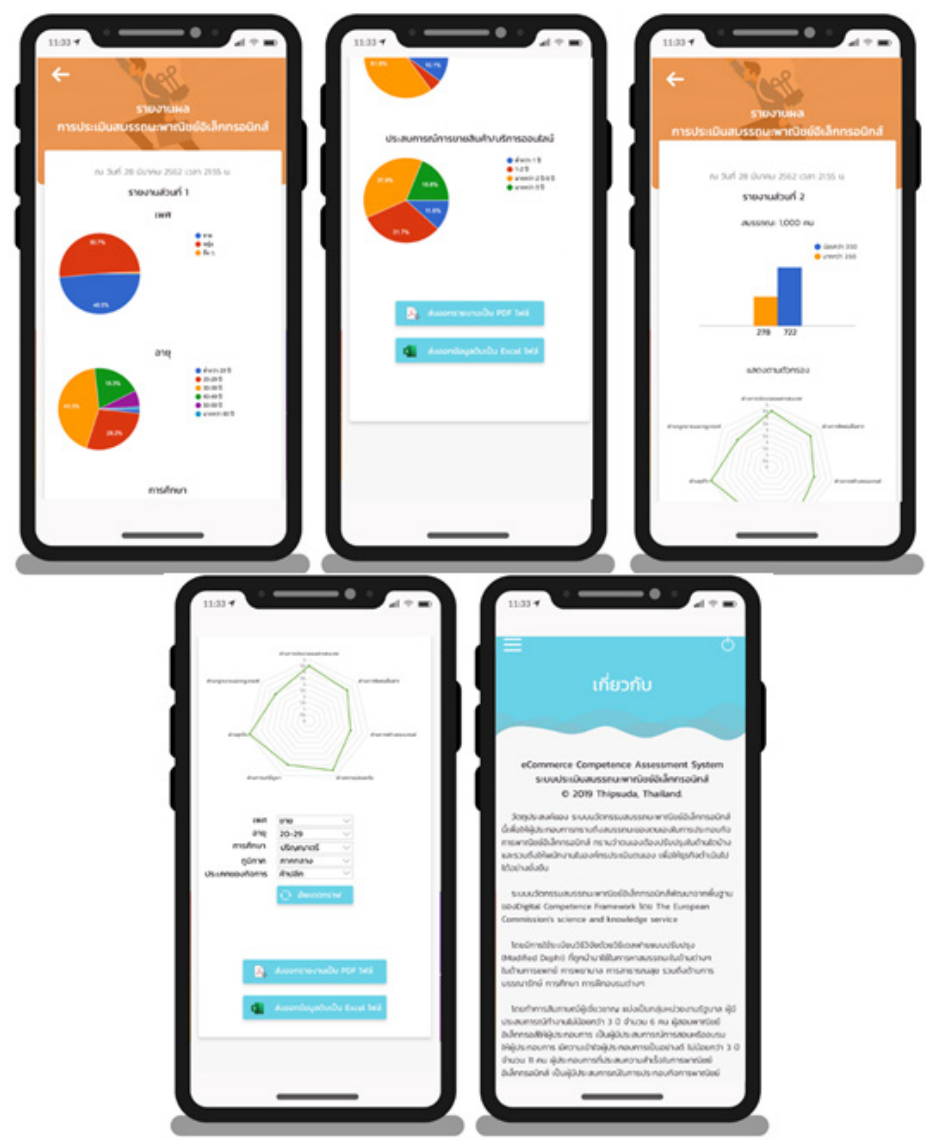

Fig. 12. Reports screenshots for Government Authority. 


\subsection{TAM}

Demographic: The results of the data analysis are from respondents who have evaluated the program and answered the questionnaire. The researcher has evaluated the system adoption from 30 entrepreneurs, as shown in Table 6.

Table 6. Demographic information

\begin{tabular}{|l|c|c|l|c|c|}
\hline \multicolumn{1}{|c|}{ Details } & n & $\%$ & \multicolumn{1}{|c|}{ Details } & n & \% \\
\hline 1. Gender & 11 & 36.7 & Less than High School & 0 & 0 \\
\hline Male & 18 & 60.0 & High School & 3 & 10.0 \\
\hline Female & 1 & 3.3 & Diploma or Equal & 3 & 10.0 \\
\hline LGBT & 1 & 3.3 & Master's Degree & 14 & 46.7 \\
\hline 2. Age & 7 & 23.3 & Doctor's Degree & 10 & 33.3 \\
\hline Less than 20 years & 18 & 60.0 & 4. e-Commerce experience & 0 & 0 \\
\hline 20-29 years & 4 & 13.3 & 1 year or less & 6 & 20.0 \\
\hline 30-39 years & 0 & 0 & 1 - 2 years & 8 & 26.7 \\
\hline $40-49$ years & 0 & 0 & 2 - 5 years & 11 & 36.7 \\
\hline $50-59$ years & & & Over 5 years & 5 & 16.7 \\
\hline 60 years or more & & & Total & 30 & 100.00 \\
\hline
\end{tabular}

There was a total of 30 respondents. The majority, 18 individuals, were women, representing $60 \%$. Most of the respondents, 18 people, were 30-39 years old, representing $60 \%$. Most of them, 14 individuals, have a bachelor's degree, representing $46.7 \%$ and 11 people have e-commerce experience of between 2 - 5 years, accounting for $36.7 \%$.

Perception of SMEs toward eCommerce Assessment Application: The adoption of technology acceptance system consists of 4 components: Perceived Usefulness, Perceived Ease of Use, Attitude Ease of Use and Intention to Use, as shown in Table 7.

Perceived Usefulness, data reveals that the respondents perceived that the use of the application systematically identified their own strengths, weaknesses and potential. Furthermore, the usefulness of this application for self-assessment and online sales received an average score of 4.50. This application is one of the most effective online self-assessment tools and overall, the use of the application is useful for your work received an average score of 4.43 . The use of applications helps improve the quality of online sales scored the lowest at 4.07.

Perceived Ease of Use, the findings show that the respondents agree it is easy to complete the self-assessment in this application and overall, it was easy to use, this statement received at average score of 4.63. The application is easy to use and does not require learning from the manual scored an average 4.47 . The question regarding the time spent on learning how to use the application received a score of 4.37 .

Attitude toward Using, according to the data, the respondents perceived that the overall attitude towards using this application was positive, an average score of 4.73. The question regarding whether the respondents thought the application is a good idea received an average score of 4.70 . Whether or not using this application is pleasant scored a 4.57 . 
Behavioral Intention to Use, the findings indicated that the respondents agreed that they were most willing to use this application in the future, receiving an average score of 4.57. Whether the respondents have the intention of recommending this application to friends who do businesses online and using the application to evaluate their own ecommerce performance received an average score of 4.50 .

Table 8 shows that all 30 participants are interested in using the system, accounting for $100 \%$ of the respondents.

Table 7. Perception of SMEs toward application

\begin{tabular}{|c|l|c|c|l|}
\hline No. & \multicolumn{1}{|c|}{ Questions } & mean & S.D. & \multicolumn{1}{|c|}{ Level } \\
\hline & Perceived Usefulness & & & \\
\hline 1 & $\begin{array}{l}\text { Using the application systematically reveals my strengths, weak- } \\
\text { nesses and potential. }\end{array}$ & 4.50 & 0.509 & Strongly agree \\
\hline 2 & The application is beneficial for online sales self-assessment. & 4.50 & 0.509 & Strongly agree \\
\hline 3 & The use of the application improves online sales performance. & 4.07 & 0.785 & Agree \\
\hline 4 & $\begin{array}{l}\text { This application is an effective tool for online sales self-assess- } \\
\text { ment. }\end{array}$ & 4.43 & 0.679 & Strongly agree \\
\hline 5 & In general, application benefits your work. & 4.43 & 0.504 & Strongly agree \\
\hline & Perceived Ease of Use & & & \\
\hline 6 & It is very easy to do the self-assessment in this application. & 4.63 & 0.669 & Strongly agree \\
\hline 7 & I think this application is easy to use. & 4.47 & 0.629 & Strongly agree \\
\hline 8 & It does not take a long time to learn to use the application. & 4.37 & 0.809 & Strongly agree \\
\hline 9 & Using the application does not require studying the manuals. & 4.47 & 0.730 & Strongly agree \\
\hline 10 & In general, the application is easy to use. & 4.63 & 0.490 & Strongly agree \\
\hline & Attitude Toward Using & & & \\
\hline 11 & Using this application is a good idea. & 4.70 & 0.535 & Strongly agree \\
\hline 12 & I think that using the application is pleasant. & 4.57 & 0.568 & Strongly agree \\
\hline 13 & In general, the attitude toward this application is positive. & 4.73 & 0.450 & Strongly agree \\
\hline & Behavioral Intention to Use & & & \\
\hline 14 & $\begin{array}{l}\text { intend to recommend the use of this application to my friends } \\
\text { who operate online businesses. }\end{array}$ & 4.50 & 0.572 & Strongly agree \\
\hline 15 & I intend to use this application in the future. & 4.57 & 0.504 & Strongly agree \\
\hline 16 & $\begin{array}{l}\text { I will definitively keep using this application for e-commerce } \\
\text { competency self-assessment. }\end{array}$ & 4.50 & 0.682 & Strongly agree \\
\hline$n=30$ & & & \\
\hline
\end{tabular}

Table 8. Interested in using the system

\begin{tabular}{|c|l|c|c|}
\hline No. & \multicolumn{1}{|c|}{ Questions } & n & Percentage \\
\hline 1 & Interested in using the system. & 30 & 100.00 \\
\hline 2 & Not interested in using the system. & 0 & 0 \\
\hline
\end{tabular}




\section{Discussion}

In summary, the results obtained indicated that E-Commerce Competence Framework consists of 8 dimensions:

1) Information Processing and Technology 2) Communication and Collaboration 3) Content Creation, which correlates with previous studies, Digital Competence Framework [16] and National E-Commerce Training Contents [21] which dictate that entrepreneurs have knowledge of computers and technologies since doing online business needs both computers and mobile phones to search, store and process information of the products.

Furthermore, communication with customers and partners are needed, therefore it is essential to have co-operation in the online system team.

Additionally, the knowledge to create interesting contents, such as images, videos, and any content that attracts customers to buy products and services is essential. The results are in accordance with the World Trade Organization (WTO) [19], whereby ecommerce defined the production, distribution, marketing, sale or delivery of goods and services by electronic means.

In regard to Safety, Security and Privacy, the entrepreneurs must carefully consider this aspect because in online transactions the customers are unable to touch the products while making a purchase, especially since transactions involve payments made through the online system, therefore priority must be given to safety and security. This includes the privacy of customers, whereby shops must maintain the confidentiality of the customers and never disclose any information without permission. This is in accordance with [16] and [50], which indicates that the level of internet safety perceptions and privacy concerns are factors that individuals with the intention to engage in online transactions must be informed about.

In regard of 5) Problem Solving and Self Development, when doing businesses on e-commerce there could be several problems, such as problems of using hardware, software or delivery to customers. For example, in one study [51] an example problem was given which e-commerce businesses sometimes encounter, which is regarding product tracking and whereby iBeacon technology was offered as a tool to follow the products. Therefore, it is necessary for entrepreneurs to have problem solving skills.

In regard to 6) Business Fundamental, this is an important competency when doing business because e-commerce is a business that is conducted online and corresponds to [20] the importance of business knowledge as well as various strategies.

As for 7) Legal and Regulations, entrepreneurs must have legal knowledge and understanding of various rules on how to conduct businesses, including tax payments. This is consistent with the research [21], which argues that online shops must be registered by form of E-Commerce registration and [52] that discusses the issue of Legal Regulation of E-Commerce.

Finally, for 8) Language, this is an important skill because e-commerce is the trading of goods without borders, therefore, it is necessary to have knowledge of an additional second language, such as English or Chinese. The findings from this study are similar to those from [53] which argues that when SMEs businesses has multilingual payment pages, portals and websites in local languages, the conversion rate can increase. 
According to the results on the adoption by TAM Model, for Perceived Usefulness, the respondents agreed that using the application helps them to systematically identify their own strengths, weaknesses and potential and this application is useful for selfevaluation for online businesses, with an average score of 4.50. Perceived usefulness was supported, which is in line with the findings from other similar studies (e.g. [54], [44], [45]). For Perceived Ease of Use, respondents agreed that it was easy to do the self-assessments in this application, and overall, it was easy to use the applications, scoring the highest average at 4.63 . This is because it was designed to be used easily and users can register and enter the self-assessment page by following the instruction, including submitting the answer or having the application display the evaluation result with no complexity. This has been verified in many studies (e.g. [55], [44] , [56], [59]). As for Attitude Toward Using, overall, the attitude towards using this application is positive with an average score of 4.73 because the system reveals online sales competency that entrepreneurs should acquire, which in turn allows assessors to identify the competency gap, which is useful for self-improvement. This makes users feel as though using the application is beneficial to them, which can be understood based on [45] and [59]. However, the intention to use the application in the future received an average score of 4.57. This finding is in line with the results obtained from other studies [46], [48], [60] which are the results from perceived usefulness and user friendliness. Finally, the data reveals that all 30 respondents, $100 \%$ of the group, are interested in using the system and in sending good feedback for the application via instant messaging. Overall, this system is beneficial for e-commerce self-development, as shown in Figure 12. This portrays the opinions of users via instant messaging expressing that the system is particularly useful in self-development in e-commerce.

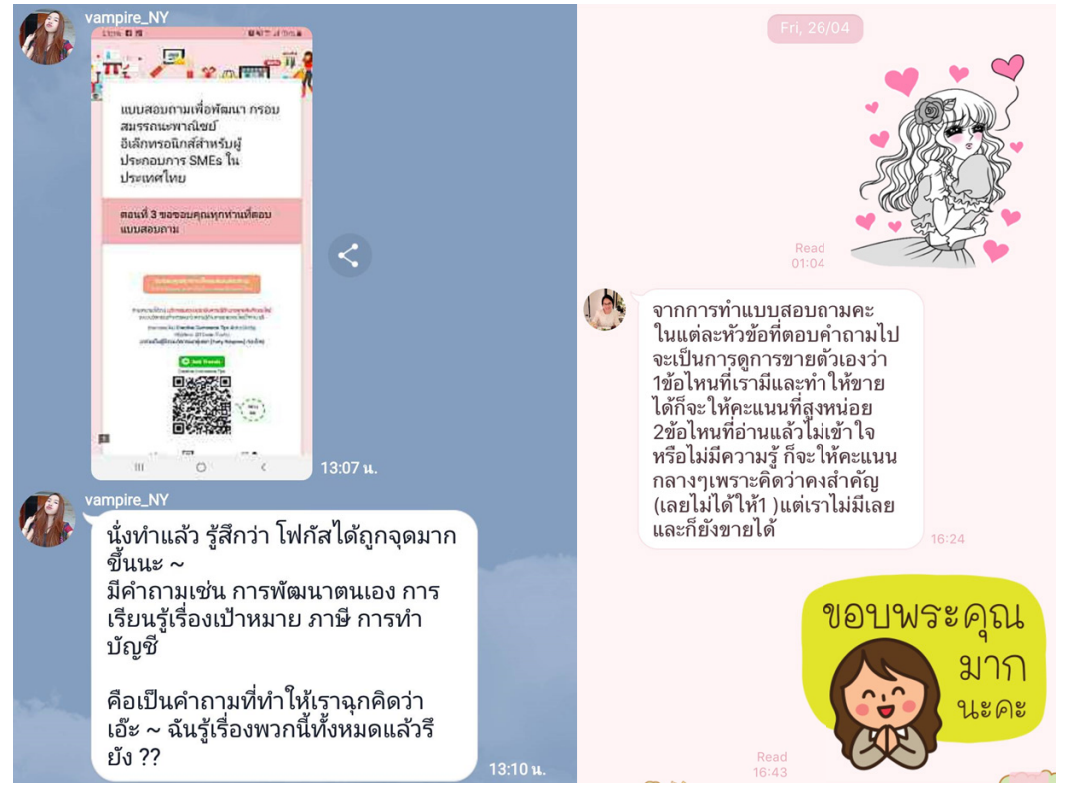

Fig. 13.User Testimonials 


\section{Conclusion}

The aim of this study was to develop an E-Commerce Competence Assessment Application, which helps entrepreneurs to identify their level of competency and improve their skills. It also gives the government agencies the ability to browse the e-commerce competency reports of entrepreneurs, which can help them to better plan for entrepreneurship training. This will enable them to utilize the budget for training entrepreneurs and becoming more effective. Furthermore, they can study the system acceptance of users with the Technology Acceptance Model (TAM).

The theoretical contribution of the study is the development of E-Commerce Competence Framework, which includes indicators that uses a based theory from Digital Competence Framework [16], E-Commerce Textbook Contents [20], and National ECommerce Training Contents [21]. An in-depth interview was conducted on 9 experts in e-commerce from 3 groups of stakeholders [40], [41], [5] related to national e-commerce development. Subsequently, the data was synthetized with Content Analysis and summarized for the E-Commerce Competence Framework, which includes a total of 8 aspects and 62 indicators.

Following this, the e-commerce competency indicators were developed into mobile applications so that they can be used to assess the capability of entrepreneurs. The system indicates the strengths and weaknesses in each area so that the individuals can improve themselves. Moreover, the system can create insight reports for government agencies officers who can use the data to retrieve information that can assist them in planning for the training and development of entrepreneurs.

In the final step of the study, the user acceptance system was studied using the Technology Acceptance Model theory (TAM), which revealed that all 30 users are interested in using this system.

The main limitation of this study is regarding the number of experts involved. For the development of the E-Commerce Competence framework, if the total number of experts increase, this would mean that a more comprehensive pool of data for each dimension of e-commerce competencies and indicators would be available. Moreover, in the process of summarizing the information obtained from the experts, if the information was sent to each expert for confirmation or a chance to change the indicators, then the data obtained may be more reliable.

For future research, it would be useful to replicate this study using a larger group of respondents in order to confirm the indicators and dimensions of E-Commerce Competence Framework.

\section{$7 \quad$ Acknowledgement}

This work is supported by the $90^{\text {th }}$ anniversary of Chulalongkorn University Fund (Ratchadaphiseksomphot Endowment Fund).We would like to thank the Electronic Transactions Development Agency (ETDA), Ministry of Digital Economy and Society, The Office of SMEs Promotion (OSMEP) and Department of Business Development, Ministry of Commerce for collaboration and kindly support for insightful suggestions. 


\section{References}

[1] K. K. Ramachandran, K. K. Karthick, and M. Saravana Kumar, Online Shopping in the UK. 2011, p. 23.

[2] L. Wu, Y. Cai, and D. Liu, "Online shopping among Chinese consumers: an exploratory investigation of demographics and value orientation," vol. 35, no. 4, pp. 458-469, 2011. https://doi.org/10.1111/j.1470-6431.2010.00982.x

[3] Euromonitor. (2017). E-Commerce Is the Fastest Growing Global Retail Channel Through 2022. Available: https://blog.euromonitor.com/e-commerce-is-the-fastest-growing-globalretail-channel-through-2022/

[4] International Post Corporation. (2017). State of e-commerce: global outlook 2016-21. Available: https://www.ipc.be/sector-data/e-commerce/articles/global-ecommerce-figures-2017

[5] Electronic Transactions Development Agency. (2018). Value of e-Commerce Survey in Thailand 2018. Available: https://www.etda.or.th/download-publishing/127/

[6] Electronic Transactions Development Agency. (2019). Value of e-Commerce Survey in Thailand 2019. Available: https://www.etda.or.th/app/webroot/content files/13/files/Value of_eCommerce_Survey_in_Thailand_2018_Slides $\% 282 \% 29$.pdf

[7] Ministry of Information and Communication Technology. (2011). Executive Summary Thailand Information and Communication Technology Policy Framework (2011-2020). Available: http://www.mdes.go.th/assets/portals/10/files/e-Publication/Executive\%20Summary\%20ICT2020.pdf

[8] Ministry of Information and Communication Technology. (2016). Thailand Digital Economy and Society Development Plan. Available: https://www.onde.go.th/assets/portals// files/Digital Thailand pocket book EN.pdf

[9] Thailand Professional Qualification Institute. (2014). Mission. Available: https://www. tpqi.go.th/aboutus-en.php

[10] S. Papadakis, S., N. Zaranis, and M. Kalogiannakis, "Parental involvement and attitudes towards young Greek children's mobile usage". International Journal of Child-Computer Interaction, 22, 100144, 2019. https://doi.org/10.1016/j.ijcci.2019.100144

[11] S. Papadakis, M. Kalogiannakis, E. Sifaki, and N. Vidakis, "Access Moodle Using Smart Mobile Phones. A Case Study in a Greek University." In A. Brooks, E. Brooks, N. Vidakis (Eds), Interactivity, Game Creation, Design, Learning, and In-novation. ArtsIT 2017, DLI 2017. Lecture Notes of the Institute for Computer Sciences, Social Informatics and Telecommunications Engineering, vol 229, (pp. 376-385), Switzerland, Cham: Springer, 2018. https://doi.org/10.1007/978-3-319-76908-0 36

[12] S. Kanofsky, "Competency-Based Medical Education for Physician Assistants: The Development of Competency-Based Medical Education and Competency Frameworks in the United States and Canada," Physician Assistant Clinics, vol. 5, no. 1, pp. 91-107, 2020/01/ 01/2020. https://doi.org/10.1016/j.cpha.2019.08.005

[13] L. Leistner and J. Carlin, "Assisted living nurse competencies," Geriatric Nursing, vol. 40, no. 2, pp. 225-227, 2019/03/01/ 2019. https://doi.org/10.1016/j.gerinurse.2019.03.005

[14] C. Johnson and A. P. Traynor, "Identifying student learning competencies for urban underserved practice using a Delphi process," Currents in Pharmacy Teaching and Learning, vol. 10, no. 6, pp. 687-694, 2018/06/01/ 2018. https://doi.org/10.1016/j.cptl.2018.03.007

[15] R. Forbes, A. Mandrusiak, M. Smith, and T. Russell, "Identification of competencies for patient education in physiotherapy using a Delphi approach," Physiotherapy, vol. 104, no. 2, pp. 232-238, 2018/06/01/ 2018. https://doi.org/10.1016/j.physio.2017.06.002

[16] European Union. (2015). DIGCOMP. Available: https://europass.cedefop.europa.eu/resources/digital-competences 
[17] A. G. Khan, "Electronic commerce: A study on benefits and challenges in an emerging economy," Global Journal of Management and Business Research, vol. 16, no. 1, 2016.

[18] L. Percival-Straunik, E-commerce. Bloomberg Press, 2001.

[19] World Trade Organization. (2019). Electronic commerce. Available: https://www.wto. org/english/tratop e/ecom e/ecom e.htm

[20] D. Chaffey, T. Hemphill, and D. Edmundson-Bird, Digital business and e-commerce management. Pearson UK, 2019.

[21] Electronic Transactions Development Agency. (2019). SMEs Go Online. Available: https://www.smesgoonline.com/page/about.php

[22] European Union. (2015). Digital competences - Self-assessment grid. Available: https:// europass.cedefop.europa.eu/sites/default/files/dc-en.pdf

[23] D. J. Attard, D. L. Ross, and K. W. Weeks, "Developing a spiritual care competency framework for pre-registration nurses and midwives," Nurse Education in Practice, vol. 40, p. 102604, 2019/10/01/ 2019. https://doi.org/10.1016/j.nepr.2019.07.010

[24] L. Cupelli, "An innovative service-learning project to develop cultural competency in undergraduate nursing students," Teaching and Learning in Nursing, vol. 11, no. 3, pp. 113117, 2016/07/01/ 2016. https://doi.org/10.1016/j.teln.2016.01.004

[25] L. Peculea, "Curricular Openings in Developing the Learning to Learn Competency: An Intervention Program for 11th Graders with Learning Difficulties," Procedia-Social and Behavioral Sciences, vol. 209, pp. 370-377, 2015/12/03/ 2015. https://doi.org/10.1016/ j.sbspro.2015.11.252

[26] Electronic Transactions Development Agency. (2012, May 3). Mission. Available: https://www.etda.or.th/background-and-mission.html

[27] W. Royce, "TRW's Ada process model for incremental development of large software systems," in [1990] Proceedings. 12th International Conference on Soft-ware Engineering, 1990, pp. 2-11: IEEE. https://doi.org/10.1109/icse.1990.63598

[28] E. Stolterman and M. Wiberg, "Compositional interaction design changes in design practice and its implications for teaching and research," Digital Creativity, vol. 31, no. 1, pp. 44-63, 2020/01/02 2020. https://doi.org/10.1080/14626268.2020.1722708

[29] R. Layona, B. Yulianto, and Y. Tunardi, "Web based Augmented Reality for Human Body Anatomy Learning," Procedia Computer Science, vol. 135, pp. 457-464, 2018/01/01/ 2018. https://doi.org/10.1016/j.procs.2018.08.197

[30] N. P. Cechetti, E. A. Bellei, D. Biduski, J. P. M. Rodriguez, M. K. Roman, and A. C. B. De Marchi, "Developing and implementing a gamification method to improve user engagement: A case study with an m-Health application for hypertension monitoring," Telematics and Informatics, vol. 41, pp. 126-138, 2019/08/01/ 2019. https://doi.org/10. 1016/j.tele.2019.04.007

[31] H.-Y. Kao, C.-W. Wei, M.-C. Yu, T.-Y. Liang, W.-H. Wu, and Y. J. Wu, "Integrating a mobile health application for self-management to enhance Telecare system," Telematics and Informatics, vol. 35, no. 4, pp. 815-825, 2018/07/01/ 2018. https://doi.org/10. 1016/i.tele.2017.12.011

[32] A. Saxena and P. J. I. J. o. I. R. Upadhyay, "Waterfall vs. prototype: Comparative study of sdlc," vol. 2, no. 6, pp. 1012-1015, 2016.

[33] M. Fishbein and I. Ajzen, "Intention and Behavior: An introduction to theory and research," ed: Addison-Wesley, Reading, MA, 1975.

[34] F. D. Davis, R. P. Bagozzi, and P. R. Warshaw, "User acceptance of computer technology: a comparison of two theoretical models," Management science, vol. 35, no. 8, pp. 982-1003, 1989. https://doi.org/10.1287/mnsc. 35.8 .982 
[35] S. Papadakis, "Evaluating pre-service teachers' acceptance of mobile devices with regards to their age and gender: A case study in Greece," International Journal of Mobile Learning and Organisation, vol. 12, p. 336, 01/01 2018. https://doi.org/10.1504/ijmlo.2018.100133 $\underline{72}$

[36] S. Papadakis, and V. Orfanakis, "The Combined Use of Lego Mindstorms NXT and App Inventor for Teaching Novice Programmers." In: Alimisis D., Moro M., Menegatti E. (Eds.), Educational Robotics in the Makers Era. Edurobotics 2016. Advances in Intelligent Systems and Computing, vol 560, pp.193-204. Springer, Cham., 2017 https://doi.org/10. $1007 / 978-3-319-55553-9 \quad 15$

[37] T. Chuchu and T. Ndoro, "An Examination of the Determinants of the Adoption of Mobile Applications as Learning Tools for Higher Education Stu-dents," International Journal of Interactive Mobile Technologies, vol. 13, no. 3, 2019. https://doi.org/10.3991/ijim.v13i03. $\underline{10195}$

[38] M. Rojas-Osorio and A. Alvarez-Risco, "Intention to Use Smartphones among Peruvian University Students," International Journal of Interactive Mobile Technologies, vol. 13, no. 3, 2019. https://doi.org/10.3991/ijim.v13i03.9356

[39] S. Singh, I. A. Zolkepli, and C. W. Kit, "New Wave in Mobile Commerce Adoption via Mobile Applications in Malaysian Market: Investigating the Relationship Between Consumer Acceptance, Trust, and Self Efficacy," International Journal of Interactive Mobile Technologies, vol. 12, no. 7, 2018. https://doi.org/10.3991/ijim.v12i7.8964

[40] Office of Small and Medium Enterprises Promotion. (2019, May 3). Mission. Available: https://www.sme.go.th/en/page.php?modulekey=73

[41] Department of Business Development. (2019, May 3). Mission. Available: https://www. dbd.go.th/dbdweb_en/ewt_news.php?nid=3936

[42] P. Surendran, "Technology acceptance model: A survey of literature," Inter-national Journal of Business Social Research, vol. 2, no. 4, pp. 175-178, 2012.

[43] R. V. Hogg, E. A. Tanis, and D. L. Zimmerman, Probability and statistical inference. Macmillan New York, 1977.

[44] R. Li, T.-L. Chung, and A. M. Fiore, "Factors affecting current users' attitude towards eauctions in China: An extended TAM study," Journal of Retailing and Consumer Services, vol. 34, pp. 19-29, 2017. https://doi.org/10.1016/j.jretconser.2016.09.003

[45] J. Pando-Garcia, I. Periañez-Cañadillas, and J. Charterina, "Business simulation games with and without supervision: An analysis based on the TAM model," Journal of Business Research, vol. 69, no. 5, pp. 1731-1736, 2016. https://doi.org/10.1016/j.jbusres.2015.10. 046

[46] Z. Dulcic, D. Pavlic, and I. Silic, "Evaluating the Intended Use of Decision Support System (DSS) by Applying Technology Acceptance Model (TAM) in Business Organizations in Croatia," Procedia-Social and Behavioral Sciences, vol. 58, pp. 1565-1575, 2012. https://doi.org/10.1016/j.sbspro.2012.09.1143

[47] W. Hong, J. Y. L. Thong, L. C. Chasalow, and G. Dhillon, "User Acceptance of Agile Information Systems: A Model and Empirical Test," Journal of Management Information Systems, vol. 28, no. 1, pp. 235-272, 2011. https://doi.org/10.2753/mis0742-1222280108

[48] C. López-Nicolás, F. J. Molina-Castillo, and H. Bouwman, "An assessment of advanced mobile services acceptance: Contributions from TAM and diffusion theory models," Information \& Management, vol. 45, no. 6, pp. 359-364, 2008. https://doi.org/10.1016/j.im. $\underline{2008.05 .001}$

[49] M.-C. Lee, "Factors influencing the adoption of internet banking: An integration of TAM and TPB with perceived risk and perceived benefit," Electronic Commerce Research and Applications, vol. 8, no. 3, pp. 130-141, 2009. https://doi.org/10.1016/j.elerap.2008.11.006 
[50] Z. A. Mohammed and G. P. Tejay, "Examining privacy concerns and ecommerce adoption in developing countries: The impact of culture in shaping individuals' perceptions toward technology," Computers \& Security, vol. 67, pp. 254-265, 2017/06/01/ 2017. https://doi. org/10.1016/j.cose.2017.03.001

[51] X. T. R. Kong et al., "Cyber physical ecommerce logistics system: An implementation case in Hong Kong," Computers \& Industrial Engineering, vol. 139, p. 106170, 2020/01/ 01/2020. https://doi.org/10.1016/j.cie.2019.106170

[52] T. T. Aliev and I. V. Bit-Shabo, "Legal Regulation of E-Commerce and Other Entrepreneurial Activities Conducted with Digital Technologies," in Artificial Intelligence: Anthropogenic Nature vs. Social Origin, Cham, 2020, pp. 807-813: Springer International Publishing. https://doi.org/10.1007/978-3-030-39319-9 89

[53] R. Chhibber and C. Chadha, "Adoption of Localization in E-commerce," in Advances in Data Sciences, Security and Applications, Singapore, 2020, pp. 419-432: Springer Singapore.

[54] N. Hajiheydari and M. Ashkani, "Mobile application user behavior in the developing countries: A survey in Iran," Information Systems, vol. 77, pp. 22-33, 2018. https://doi.org/10. 1016/j.is.2018.05.004

[55] L. Carter and F. Bélanger, "The utilization of e-government services: citizen trust, innovation and acceptance factors," Information Systems Journal, vol. 15, no. 1, pp. 5-25, 2005. https://doi.org/10.1111/j.1365-2575.2005.00183.x

[56] L. D. Booker, B. Detlor, and A. Serenko, "Factors affecting the adoption of online library resources by business students," Journal of the American Society for Information Science and Technology, vol. 63, no. 12, pp. 2503-2520, 2012. https://doi.org/10.1002/asi.22723

[57] M. Kalogiannakis and S. Papadakis, S. "Evaluating pre-service kindergarten teachers' intention to adopt and use tablets into teaching practice for natural sciences." Int. J. Mobile Learning and Organisation, 13, 1, 113-127, 2019. https://doi.org/10.1504/ijmlo.2019.100 $\underline{16617}$

[58] St. Papadakis, St., \& M. Kalogiannakis, M. (2017). Combining mobile technologies in environmental education: A Greek case study. International Journal of Mobile Learning and Organisation, (Special Issue on Mobile Learning Applications and Strategies), 11(3), 256277, 2017. https://doi.org/10.1504/ijmlo.2017.10005249

[59] F. Muñoz-Leiva, S. Climent-Climent, and F. Liébana-Cabanillas, "Determinants of intention to use the mobile banking apps: An extension of the classic TAM model," Spanish Journal of Marketing - ESIC, vol. 21, no. 1, pp. 25-38, 2017. https://doi.org/10.1016/j. sjme.2016.12.001

[60] J. C. Sánchez-Prieto, S. Olmos-Migueláñez, and F. J. García-Peñalvo, "MLearning and preservice teachers: An assessment of the behavioral intention using an expanded TAM model," Computers in Human Behavior, vol. 72, pp. 644-654, 2017. https://doi.org/10. $\underline{1016 / j . c h b .2016 .09 .061}$

\section{Authors}

Thipsuda Wongkhamdi is currently a $\mathrm{PhD}$ candidate from Technopreneurship and Innovation Management Program, Chulalongkorn University. She received her bachelor's degree in Business Information Technology there. At present, she is doing research in the fields of Digital Business, eCommerce and Digital Marketing. Thipsuda.W@student.chula.ac.th 
Nagul Cooharojananone is an associate professor at Chulalongkorn University, Thailand. He received his B.S. degree In Computer Science from Mahidol University. He received his M.Engg and Ph.D. in Information and Communication Engineering from the University of Tokyo. His research interests include Multimedia Technology and Mobile Application. Nagul.C@,chula.ac.th

Jintavee Khlaisang is an associate professor at the Department of Educational Technology and Communications, and a member of Educational Invention and Innovation research unit, Faculty of Education, Chulalongkorn University. Jintavee is also the deputy director of Thailand Cyber University Project, Ministry of Higher Education, Science, Research and Innovation, Thailand. Her research interests including E-learning, flipped classroom, Blended Learning Environment, Virtual Learning Environment, Ubiquitous Learning, Disruptive Technology and MOOCs. Jintavee.M@chula.ac.th

Article submitted 2019-07-30. Resubmitted 2020-03-31. Final acceptance 2020-04-02. Final version published as submitted by the authors. 


\section{Appendix A}

Table 9. E-Commerce Competence Assessment Framework

\begin{tabular}{|c|c|c|}
\hline Dimensions & No. & Competences \\
\hline \multirow{6}{*}{$\begin{array}{l}\text { Cat 1: Information Pro- } \\
\text { cessing and Technology }\end{array}$} & 1 & Being able to use the internet \\
\hline & 2 & $\begin{array}{l}\text { Being able to perform online transactions on Mobile Banking applica- } \\
\text { tions }\end{array}$ \\
\hline & 3 & Being able to use the computer to perform searching \\
\hline & 4 & $\begin{array}{l}\text { Being aware which online marketplace has potential customers (Lazada, } \\
\text { Shopee, Website, IG) }\end{array}$ \\
\hline & 5 & Being able to perform basic computer operations (Copy and save files) \\
\hline & 6 & Being familiar with smartphones. \\
\hline \multirow{7}{*}{$\begin{array}{l}\text { Cat 2: Communication } \\
\text { and Collaboration }\end{array}$} & 7 & Being aware of customer engagement channels (Facebook, Line, Email) \\
\hline & 8 & Being careful of words and language with online customers \\
\hline & 9 & $\begin{array}{l}\text { Being able to evaluate which engagement platform results in more sales } \\
\text { (Facebook messenger, Line, Tel., Line@) }\end{array}$ \\
\hline & 10 & Being able to impress and convince customers \\
\hline & 11 & Being aware of how the customers reply \\
\hline & 12 & $\begin{array}{l}\text { Being able to measure and calculate expenses from communication de- } \\
\text { vices. }\end{array}$ \\
\hline & 13 & Being aware of online manners. \\
\hline \multirow[t]{7}{*}{ Cat 3: Content Creation } & 14 & Being able to present Selling point (strength of the products). \\
\hline & 15 & Being aware of any copyrighted content \\
\hline & 16 & Being able to use content to raise the value of the product. \\
\hline & 17 & Being able to describe the product as a story \\
\hline & 18 & Being to distinctively present the product based on the personality \\
\hline & 19 & $\begin{array}{l}\text { Being aware of which content type (picture or content) has the most im- } \\
\text { pact on customers decisions. }\end{array}$ \\
\hline & 20 & $\begin{array}{l}\text { Being aware of any limitations of the online marketing platforms. (Not } \\
\text { too many texts in images on Facebook) }\end{array}$ \\
\hline \multirow{12}{*}{$\begin{array}{l}\text { Cat } 4 \text { : Safety, Security } \\
\text { and Privacy }\end{array}$} & 21 & Being careful when using credit cards to perform online transactions. \\
\hline & 22 & Being aware not to use customer's data without permission. \\
\hline & 23 & Being aware that passwords need to be protected. \\
\hline & 24 & Being aware of payment methods and choices for customers to make. \\
\hline & 25 & Being aware of fraud and scams, evaluate any content before sharing. \\
\hline & 26 & Being understand of customer's privacy \\
\hline & 27 & Being able to backup customer data in case of loss. \\
\hline & 28 & $\begin{array}{l}\text { Being able to gain customers trust when performing online transactions } \\
\text { with credit cards. }\end{array}$ \\
\hline & 29 & Being able to store and secure the customer's data. \\
\hline & 30 & $\begin{array}{l}\text { Being able to understand security awareness and cyber security such as } \\
\text { hacking. }\end{array}$ \\
\hline & 31 & $\begin{array}{l}\text { Being able to use provided features on the platforms (Creating a secret } \\
\text { group on Facebook). }\end{array}$ \\
\hline & 32 & $\begin{array}{l}\text { Being able to maintain good device using behaviours. (Using Antivirus, } \\
\text { password protection) }\end{array}$ \\
\hline \multirow[t]{3}{*}{$\begin{array}{l}\text { Cat 5: Problem Solving } \\
\text { and Self Development }\end{array}$} & 33 & $\begin{array}{l}\text { Being aware of self-development on the aspect that needs more profi- } \\
\text { ciency. (art, content writing) from both online and offline sources. }\end{array}$ \\
\hline & 34 & Being able to address issues that may occur to the customer. (Tracking) \\
\hline & 35 & Being able to fix the basic problems of the device such as restarting. \\
\hline
\end{tabular}




\begin{tabular}{|c|c|c|}
\hline Dimensions & No. & Competences \\
\hline & 36 & $\begin{array}{l}\text { Being able to seek and find a person/organization to help in case of criti- } \\
\text { cal issues (Photoshop Editing). }\end{array}$ \\
\hline & 37 & $\begin{array}{l}\text { Being able to analyze data into numbers, compare and create the most ef- } \\
\text { ficient workflow. }\end{array}$ \\
\hline & 38 & Being aware of plans for customers in case of issues (FAQ) \\
\hline & 39 & Being able to create a personal brand and present yourself. \\
\hline & 40 & Being able to maintain connections to both online and offline customers. \\
\hline & 41 & Being honest to the customers. \\
\hline \multirow{15}{*}{$\begin{array}{l}\text { Cat 6: Business Funda- } \\
\text { mental }\end{array}$} & 42 & Being able to make returning customers, provide good services/products. \\
\hline & 43 & Being able to provide higher than expected products/services \\
\hline & 44 & Being able to sell on pain points. \\
\hline & 45 & Being able to analyze customers' geography. \\
\hline & 46 & Being able to lay out a business plan \\
\hline & 47 & $\begin{array}{l}\text { Being aware of business basics (4P, STP: Segmentation, Target, Position- } \\
\text { ing) }\end{array}$ \\
\hline & 48 & Being aware of your strength/weakness as well as the competitors'. \\
\hline & 49 & $\begin{array}{l}\text { Being able to evaluate and select the most compatible sale channels ac- } \\
\text { cording to the business. Know which channel has any significant impact } \\
\text { on the business. }\end{array}$ \\
\hline & 50 & $\begin{array}{l}\text { Being aware of the difference and able to select the appropriate shipping } \\
\text { method with both vendors and customers (Registered, ems, PB, Drop off, } \\
\text { DHL Kerry Thaipost }\end{array}$ \\
\hline & 51 & Being aware of the business value chain. Choose the appropriate vendor. \\
\hline & 52 & Being able to create promotions to attract customers. \\
\hline & 53 & Being able to close deals. \\
\hline & 54 & Being able to perform accounting tasks. \\
\hline & 55 & $\begin{array}{l}\text { Being aware of e-Commerce models (B2B, B2C) and Social commerce } \\
\text { (Facebook). }\end{array}$ \\
\hline & 56 & Being aware of good service mind. \\
\hline \multirow{4}{*}{$\begin{array}{l}\text { Cat 7: Legal and Regula- } \\
\text { tions }\end{array}$} & 57 & Being aware of taxes. \\
\hline & 58 & Being aware of copyrights, branding and intellectual property. \\
\hline & 59 & Being aware of commercial license as well as e-commercial one. \\
\hline & 60 & Being aware of computer laws or any online service-related laws. \\
\hline \multirow[t]{2}{*}{ Cat 8: Languages } & 61 & $\begin{array}{l}\text { Being able to read and write in English. To read product information and } \\
\text { can search for related products. }\end{array}$ \\
\hline & 62 & Being able to use translation tools. \\
\hline
\end{tabular}

